\title{
Dry Age-Related Macular Degeneration - Prevention with A Plant-Based Diet
}

\author{
Stewart D Rose and Amanda J Strombom* \\ Plant-Based Diets in Medicine, USA
}

Submission: October 07, 2021; Published: December 02, 2021

*Corresponding author: Amanda Strombom, Plant-Based Diets in Medicine, 12819 SE 38th St, \#427, Bellevue, WA 98006

\begin{abstract}
Age-related macular degeneration (ARMD) is the leading cause of blindness in the developed world. No effective therapy exists for the dry form of ARMD, which makes up about $90 \%$ of cases. Major modifiable risk factors have been identified such as cigarette smoking, obesity, nutritional factors, and alcoholism. The risk of dry ARMD is increased by several modifiable etiologic factors in particular - lack of blue light filtration, oxidative stress, and inflammation. Two components of plant foods, lutein and zeaxanthin, screen out blue light, resulting in greater macular pigment optical density (MPOD), and act as antioxidants in the macular. A plant-based diet also reduces inflammation and lowers hsCRP. These factors combine to give vegetarians a lower risk of dry ARMD. Epidemiological studies have shown that consuming meat raises the risk of dry ARMD while consuming plant foods lowers the risk. Studies have shown significant correlations between high lutein concentration in ocular tissues or in serum and reduced risk of ARMD. Vegetarians have been found to have a greater MPOD. A broad range of antioxidants from plant foods, sulforaphane, can reduce oxidative damage, and may decrease the risk of dry ARMD. Elevated levels of hsCRP, a marker of inflammation, predict greater future risk of ARMD. On a vegan diet hsCRP was reduced 32\%, even more than on the American Heart Association diet.

Keywords: Antioxidants; ARMD; Blindness; Inflammation; Lifestyle; Lutein; Macular pigment optical density; Oxidative stress; Vegan; Zeaxanthin Abbreviations: ARMD: Age-Related Macular Degeneration, HSCRP: High-Sensitivity C-Reactive Protein, MPOD: Macular Pigment Optical Density; PUFA: Poly-Unsaturated Fatty Acids; ROS: Reactive Oxygen Species; SFN: Sulforaphane
\end{abstract}

\section{Introduction}

Age-related macular degeneration (ARMD) is the leading cause of blindness in the developed world [1,2]. It is becoming similarly important in the developing world in association with increasing longevity and Westernization of diet and lifestyle [3]. ARMD may be classified as dry or wet. While geographic atrophy may occur in both the wet and dry forms of ARMD, it is better characterized in the dry form [4]. It is characterized by sharply demarcated areas of hypopigmentation in which choroidal blood vessels are more visible than in surrounding areas [5,6]. Choroidal neovascularization (CNV) is more commonly seen in the wet form of ARMD. The dry form of ARMD is also known as non-exudative, non-neovascular, or atrophic ARMD. This is the more common form of ARMD, seen in about $90 \%$ of cases [7]. At present, no effective therapy exists for dry ARMD [8]. Dry ARMD is a multifactorial disease, having both genetic, age and modifiable risk factors [9]. The strongest risk factor is age: late ARMD can be found primarily in those aged 70 years and older $[10,11]$. The risk of ARMD is greater in persons with a family history of the disease than in those without [12] Observational studies have identified major modifiable risk factors such as cigarette smoking, obesity, nutritional factors, and alcoholism [9]. The risk of dry ARMD is increased by three modifiable etiologic factors in particular - lack of blue light filtration, oxidative stress, and inflammation. Two components of plant foods, lutein and zeaxanthin, screen out blue light and act as antioxidants in the macular. A plant-based diet also reduces inflammation. Therefore, we would expect a plantbased diet to contribute to a lower incidence of dry ARMD.

\section{Epidemiology}

Epidemiological studies have demonstrated that consuming meat increases the risk of dry ARMD while consuming plant foods decreases the risk. However, it should be noted that most epidemiological studies on ARMD do not distinguish between wet and dry ARMD [13]. Since most cases are the dry form of the disease, the results of research can be said to be broadly applicable. One study showed that a high consumption of red meat (fresh or processed) increased the risk of developing ARMD. That risk was over two times greater with processed meat, such as salami or sausage [14]. The Mediterranean diet pattern is characterized by high consumption of plant-based foods and fish 
and low consumption of meat and dairy products. In one study, adherence to the diet was associated with a $41 \%$ reduced risk of incident advanced ARMD. These findings support the role of a diet rich in healthful nutrient-rich foods such as fruits, vegetables, legumes, and fish in the prevention of ARMD [15]. People who follow a vegetarian diet have a greater macular pigment optical density (MPOD), affording them greater protection from blue light and greater levels of antioxidants, $[16,17]$ resulting in a lower risk of dry ARMD. One study showed that their MPOD was about $18 \%$ higher in vegetarian subjects compared to non-vegetarian subjects [18].

\section{Pathophysiology}

\section{Lutein and zeaxanthin}

Lutein and zeaxanthin are structural isomers that belong to a class of molecules called carotenoids. Carotenoids, which are primarily plant-derived lipophilic pigments, are essential factors in human health and development. Specifically, they function in a wide range of biological processes, including reproduction, embryonic development, immunity, and vision. In the eyes, they help provide coloration and absorption of light energy. Carotenoids may be divided into two general classes: carotenes and xanthophylls. Carotenes are non-polar molecules, which contain only carbon and hydrogen atoms, whereas xanthophylls are polar carotenoids, containing at least one oxygen atom [19]. Lutein and zeaxanthin are xanthophylls biochemically distinct from other carotenoids due to the presence of hydroxyl groups located at each end of these molecules. This functionality allows xanthophylls to be oriented in lipid membranes exposed to aqueous environments in a special and possibly protective way [20]. The xanthophylls (lutein and zeaxanthin) account for 20$30 \%$ of total carotenoids in human serum and $80-90 \%$ of total carotenoids in the human retina [21] the highest concentrations anywhere in the human body, suggesting an important functional role for these molecules in the retina [22] Figure 1. Chemical structure of Zeaxanthin, Meso-Zeaxanthin and Lutein [23].

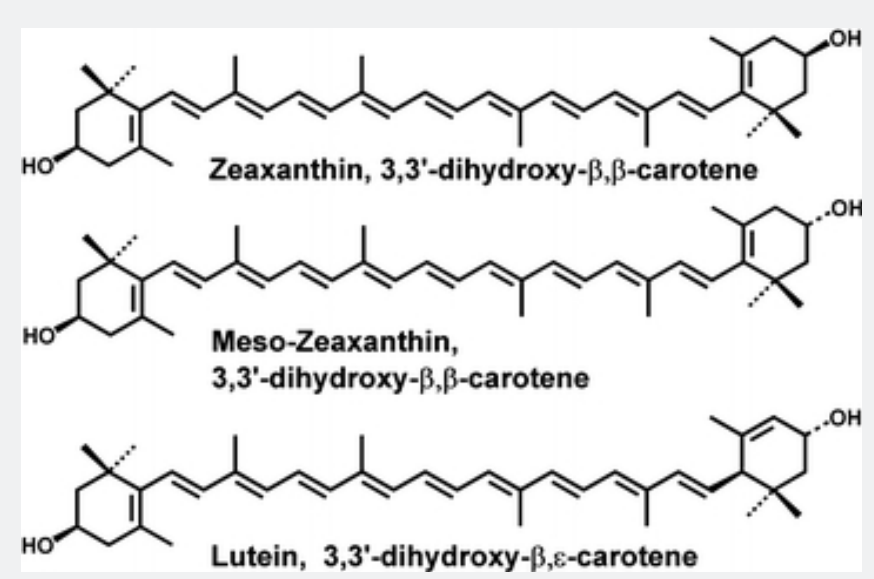

Figure 1: Chemical structure of Zeaxanthin, Meso-Zeaxanthin and Lutein.

Lutein and zeaxanthin confer macular protection via antioxidant and light-screening properties [24]. Meso-zeaxanthin is a relatively recently discovered structural isomer of zeaxanthin and appears to be a metabolite of lutein or zeaxanthin. It also has both light filtering and antioxidant properties [25]. It has been shown that lutein and zeaxanthin are entirely of dietary origin, humans cannot synthesize lutein and zeaxanthin de novo. [16,17] This is evidenced by the fact that lutein and zeaxanthin levels in the diet, serum, and retina correlate. [26]. We have adapted a capacity for efficient lutein and zeaxanthin uptake [27,28], transport $[29,30]$, retention [31-34] and protection [35] in the retina. The efficient operation of these processes may be indicated by the physiologic significance of lutein and zeaxanthin in retinal health and disease. The levels of macular pigments, usually measured in terms of the macular pigment optical density (MPOD), can reflect retinal health status [36-40]. An inverse association between macular pigment density and ARMD has long been recognized
[41-42]. Studies have shown significant correlations between high lutein concentration in ocular tissues or in serum and reduced risk of ARMD [43-45].

\section{Oxidative stress}

Oxidative damage may play an important role in the pathogenesis of dry ARMD. Oxidative stress, which refers to cellular damage caused by reactive oxygen species (ROS), has been implicated in many disease processes, especially age-related disorders. ROSs include free radicals, hydrogen peroxide, and singlet oxygen, and they are often the byproducts of oxygen metabolism [46]. Oxidative stress is a major risk factor for the pathological development of retinal diseases and vision impairment. With age, the retinal pigment epithelium (RPE) and the space between the RPE and Bruch's membrane gradually accumulate lipofuscin, a heterogeneous fluorescent mixture rich in lipid-protein complexes, which is also composed 
of by-products of vitamin A metabolism and lipid peroxidation [47-49]. Lipofuscin is undegradable and also acts as a plausible photosensitizer, generating ROS [50]. The retina is particularly susceptible to oxidative stress because of its high oxygen consumption, its exposure to light (photo-oxidation), and its exposure to high levels of ROS acting on PUFA content, including docosahexaenoic acid (DHA) [51-52]. Complement proteins have been found in histological specimens of eyes with dry ARMD. Altered levels of both intrinsic complement proteins and activated products have been found in the circulation of patients with dry ARMD. Complement activation may be triggered by oxidative stress, resulting from retinal exposure to incoming light [53].

Unfortunately, as we age, oxidative damage increases and antioxidant capacity decreases, as does the efficiency of reparative systems [54]. It appears that these age-related oxidative changes are characteristic indicators of early dry ARMD, which, in combination with hereditary susceptibility and other retinal modifiers, can progress to the pathology and visual morbidity associated with advanced dry ARMD. A broad range of antioxidants, known to have chemical properties that can reduce oxidative damage, have been proposed to decrease the risk of dry ARMD, $[36,55,56]$ in particular sulforaphane. Sulforaphane (SFN) is an isothiocyanate molecule present in cruciferous vegetables, broccoli being the most relevant example of a natural SFN source. (57) Two studies demonstrated the antioxidant potential of SFN on human RPE cells exposed to oxidant agents, including different chemical oxidative stressors and light exposition [58,59]. The mechanism by which sulforaphane accomplishes this has been determined [60]. SFN induces the expression of the phase 2 genes, through activation of the Nrf2. These genes encode for different antioxidant enzymes, including glutathione transferases or NAD(P)H dehydrogenase quinone [60]. The mechanism of action of SFN is based on the dissociation of the transcription factor Nrf2 of Keap1, a cytosolic repressor, promoting its translocation to the nucleus and inducing an antioxidant response. The binding of Nrf2 to the DNA promoter region antioxidant-responsive element (ARE), triggers the nuclear antioxidant response, through an increased expression and activity of reductive systems $[61,62]$.

A plant-based diet protects against chronic oxidative-stressrelated diseases. Dietary plants contain variable chemical families and amounts of antioxidants. Plant antioxidants may contribute to the beneficial health effects of dietary plant foods [63]. On average plant foods provide $11.57 \mathrm{mmol} / 100 \mathrm{gm}$ antioxidant content, while animal foods provide only on average $0.18 \mathrm{mmol} / 100 \mathrm{gm}$ [63]. It is therefore to be expected that a plant-based diet could decrease the risk and progression of dry ARMD through reducing oxidative stress.

\section{Inflammation}

Inflammation also plays a significant role in the incidence and progression of dry ARMD [64-66]. Drusen, subretinal deposits indicative of the onset of ARMD, have been shown to contain fibrinogen, vitronectin, complement components, and highsensitivity C-reactive protein (hsCRP), proteins associated with generalized inflammation [67-69]. Inflammatory cell debris has also been isolated from the outer surface of the Bruch's membrane in eyes with dry ARMD [70]. Pooled findings from 5 prospective cohorts show that elevated levels of hsCRP predict greater future risk of ARMD [71]. Lower levels of hsCRP were found in those following a vegetarian diet for more than 2 years [72-73]. An interventional study found that after 8 weeks on a vegan diet hsCRP was reduced 32\%, even more than on the American Heart Association diet [74].

\section{Clinical considerations}

To help prevent dry ARMD, patients should be encouraged to eat plenty of foods containing lutein and zeaxanthin along with other plant foods containing antioxidants, as a part of a healthy plant-based diet. Lutein can be found in several vegetables such as kale, spinach, romaine lettuce, broccoli, and some nuts such as pistachio nuts. Zeaxanthin can be found in foods such as corn, orange peppers, mango, and orange juice. [75-76]. Supplements are also available, and some studies indicate that they may slow the progression of ARMD [77]. Bilberry and lingonberry extracts may also have a protective effect against blue light photooxidation through their antioxidant properties [78-81]. Despite initial enthusiasm, a meta study found that fish oil supplements (omega 3 LCPUFA) supplementation in people with ARMD for periods up to five years does not reduce the risk of progression to advanced ARMD or the development of moderate to severe visual loss [82].

A plant-based diet can be very efficacious in the prevention and treatment of comorbidities such as hypercholesterolemia and type 2 diabetes. For instance, the plant-based diet is as efficacious as Lovastatin in treating hypercholesterolemia and is more efficacious than Metformin in treating type 2 diabetes [83,84]. It also reduces the risk of several other pathologies such as coronary artery disease, [83] stroke, [85], osteoarthritis, [86] prostate and colon cancer, $[87,88]$ diverticular disease, [89] ulcerative colitis, [90] Crohn's disease, [91] Grave's disease, Hashimoto's thyroiditis [92] and rheumatoid arthritis [93] just to name a few. When treating comorbidities, it's important to titrate relevant medications as the effect of the plant-based diet become evident. Lab work should also be done before starting treatment with a plant-based diet and then 6 to 8 weeks afterwards, since the therapeutic effects of a plant-based diet often take several weeks to become evident.

\section{Discussion}

There is currently no treatment for non-neovascular ARMD. Therefore, prevention, always of prime importance, becomes even more important. As longevity has increased in the developed world, the prevention of chronic diseases is needed even more than before. Oxidative stress seems to be one of the etiologic factors in dry ARMD. The plant-based diet, rich with antioxidants, can help 
reduce oxidation and therefore help prevent dry ARMD. Vegans have lower levels of hsCRP which indicates less inflammation, which reduces the risk of dry ARMD. The increased consumption of lutein and zeaxanthin and the greater MPOD that vegetarians have can also help prevent dry ARMD.

It's notable that plant foods supply both zeaxanthin and lutein along with fiber but with little saturated fats. The plant-based diet has no contraindications or adverse effects. It can help treat several common comorbidities. One weakness of this research review is that much of the research fails to report the type of ARMD studied. Since $90 \%$ of the cases of ARMD are dry ARMD, this is unlikely to change the conclusion.

\section{References}

1. Evans J, Fletcher A, Wormald R (2004) Age-related macular degeneration causing visual impairment in people 75 years or older in Britain: an add-on study to the Medical Research Council Trial of Assessment and Management of Older People in the Community. Ophthalmology 111(3): 513-517.

2. Resnikoff S, Pascolini D, Etya'ale D, Kocur I, Pararajasegaram R, et al. (2004) Global data on visual impairment in the year 2002. Bull World Health Organ 82(11): 844-851.

3. Krishnan T, Ravindran R, Murthy G, Vashist P, Fitzpatrick K, et al. (2010) Prevalence of early and late age-related macular degeneration in India: the INDEYE study. Invest Ophthalmol Vis Sci 51(2): 701-707.

4. Kumar N, Mrejen S, Fung A, Marsiglia M, Loh B, et al. (2013) Retinal pigment epithelial cell loss assessed by fundus autofluorescence imaging in neovascular age-related macular degeneration. Ophthalmology 120(2): 334-341.

5. Bird AC, Bressler NM, Bressler SB, Chisholm IH, Coscas G, et al. (1995) An international classification and grading system for age-related maculopathy and age-related macular degeneration. Surv Ophthalmol 39(5): 367-374.

6. Marsiglia M, Boddu S, Bearelly S, Xu L, Breaux BE (2013) Association between geographic atrophy progression and reticular pseudodrusen in eyes with dry age-related macular degeneration. Invest Ophthalmol Vis Sci 54(12): 7362-7369.

7. Buschini E, Piras A, Nuzzi R, Vercelli A (2011) Age related macular degeneration and drusen: neuroinflammation in the retina. Prog Neurobiol 95(1):14-25.

8. Van Lookeren Campagne M, LeCouter J, Yaspan B, Ye W (2014) Mechanisms of age-related macular degeneration and therapeutic opportunities. J Pathol 232(2): 151-164.

9. Sobrin L, Seddon JM (2014) Nature and nurture- genes and environment- predict onset and progression of macular degeneration. Prog Retinal Eye Res 40: 1-15.

10. Augood C, Vingerling J, de Jong P, Chakravarthy U, Seland J, et al. (2006) Prevalence of age-related maculopathy in older Europeans: the European Eye Study (EUREYE). Arch Ophthalmol 124(4): 529-535.

11. Jager R, Mieler W, Miller J (2008) Age-related macular degeneration. $N$ Engl J Med 358(24): 2606-2617.

12. Shahid H, Khan JC, Cipriani V, Sepp T, Matharu BK, et al. (2012) Agerelated macular degeneration: the importance of family history as a risk factor. Br J Ophthalmol 96(3): 427-431.

13. Taylor DJ, Hobby AE, Binns AM, Crabb DP (2016) How does age-related macular degeneration affect real-world visual ability and quality of life? A systematic review. BMJ Open 6(12): e011504.
14. Chong E, Simpson J, Robman L, Hodge A, Aung K, et al. (2009) Red meat and chicken consumption and its association with age-related macular degeneration. Am J Epidemiol 169(7): 867-876.

15. Merle BMJ, Colijn JM, Cougnard-Grégoire A, de Koning-Backus A, Delyfer M, et al. (2019) Mediterranean Diet and Incidence of Advanced Age-Related Macular Degeneration. Ophthalmology 126(3): 381-390.

16. Johnson E, Neuringer M, Russell R, Schalch W, Snodderly D (2005) Nutritional manipulation of primate retinas, III: Effects of lutein or zeaxanthin supplementation on adipose tissue and retina of xanthophyll-free monkeys. Invest Ophthalmol Vis Sci 46(2): 692-702.

17. Malinow M, Feeney-Burns L, Peterson L, Klein M, Neuringer M (1980) Diet-related macular anomalies in monkeys. Invest Ophthalmol Vis Sci 19(8): 857-863.

18. Hammond B (2002) Macular pigment density is increased in vegetarians. Invest Ophthalmol Vis Sci 43(1): 3604.

19. Bone RA, Landrum JT, Hime GW, Cains A, ZamorJ(1993) Stereochemistry of the human macular carotenoids. Investig Ophthalmol Vis Sci 34(6): 2033-2040.

20. Gruszecki W, Sielewiesiuk J (1990) Orientation of xanthophylls in phosphatidylcholine multibilayers. Biochim Biophys Acta. 1023(3): 405-412.

21. Handelman GJ, Snodderly DM, Adler AJ, Russett MD, Dratz EA (1992) Measurement of carotenoids in human and monkey retinas. Methods Enzymol 213: 220-230.

22. Handelman G, Dratz E, Reay C, van Kuijk J (1988) Carotenoids in the human macula and whole retina. Invest Ophthalmol Vis Sci. 29(6): 850-855.

23. Lima VC, Rosen RB, Farah M (2016) Macular pigment in retinal health and disease. Int J Retin Vitr 2: 19.

24. Landrum JT, Bone RA, Joa H, Kilburn MD, Moore LL, et al. (1997) A one year study of the macular pigment: The effect of 140 days of a lutein supplement. Exp Eye Res 65(1): 57-62.

25. Nolan J, Meagher K, Kashani S, Beatty S (2013) What is mesozeaxanthin, and where does it come from? Eye (Lond) 27(8): 899-905.

26. Beatty S, Nolan J, Kavanagh H, O’Donovan O (2004) Macular pigment optical density and its relationship with serum and dietary levels of lutein and zeaxanthin. Arch Biochem Biophys 430(1): 70-76.

27. Handelman G, Snodderly D, Krinsky N, Russett M, Adler A (1991) Biological control of primate macular pigment. Biochemical and densitometric studies. Invest Ophthalmol Vis Sci 32(2): 257-267.

28. Li B, Vachali P, Bernstein P (2010) Human ocular carotenoid-binding proteins. Photochem Photobiol Sci 9(11): 1418-1425.

29. Li B, Vachali P, Frederick J, Bernstein P (2011) Identification of StARD3as a lutein-binding protein in the macula of the primate retina. Biochemistry 50(13): 2541-2549.

30. Bhosale P, Larson A, Frederick J, Southwick K, Thulin C, et al. (2004) Identification and characterization of a $\mathrm{Pi}$ isoform ofglutathione S-transferase (GSTP1) as a zeaxanthin-binding protein in the macula of the human eye. J Biol Chem 279(47): 49447-49454.

31. Bone R, Landrum J, Guerra L, Ruiz C (2003) Lutein and zeaxanthin dietary supplements raise macular pigment density and serum concentrations of these carotenoids in humans. J Nutr 133(4): 992998.

32. Hammond B, Jr. Johnson E, Russell R, Krinsky N, Yeum K, et al. (1997) Dietary modification of human macular pigment density. Invest Ophthalmol Vis Sci 38(9): 1795-1801. 
33. Hammond B, Jr Wooten B, Snodderly D (1997) Individual variations in the spatial profile of human macular pigment. J Opt Soc Am A OptImage Sci Vis 14(6): 1187-1196.

34. Zeimer M, Hense H, Heimes B, Austermann U, Fobker M, et al. (2009) The macular pigment: short- and intermediate-termchanges of macular pigment optical density following supplementation with lutein and zeaxanthin and co-antioxidants. The LUNAStudy. Ophthalmologe 106(1): 29-36.

35. Snodderly D (1995) Evidence for protection against age-related macular degeneration by carotenoids and antioxidant vitamins. Am J Clin Nutr 62(6 Suppl): 1448S-1461S.

36. Bernstein P, Li B, Vachali P, Gorusupudi A, Shyam R, et al. (2016) Lutein, zeaxanthin, and meso-zeaxanthin: The basic and clinical science underlying carotenoid-based nutritional interventions against ocular disease. Prog retinal eye res 50: 34-66.

37. Ozawa Y, Shigeno Y, Nagai N, Suzuki M, Kurihara T, et al. (2017) Absolute and estimated values of macular pigment optical density in young and aged Asian participants with or without age-related macular degeneration. BMC Ophthalmol 17(1): 161.

38. Loane E, Kelliher C, Beatty S, Nolan J (2008) The rationale and evidence base for a protective role of macular pigment in age-related maculopathy. Br J Ophthalmol 92(9): 1163-1168.

39. Sabour-Pickett S, Nolan J, Loughman J, Beatty S (2012) A review of the evidence germane to the putative protective role of the macular carotenoids for age-related macular degeneration. Mol nutr food res 56(2): 270-286

40. Puell M, Palomo-Alvarez C, Barrio A, Gomez-Sanz F, Perez-Carrasco M (2013) Relationship between macular pigment and visual acuity in eyes with early age-related macular degeneration. Acta ophthalmologica 91(4): e298-e303.

41. Moeller SM, Parekh N, Tinker L, Ritenbaugh C, Blodi B, et al. (2006) Associations between intermediate age-related macular degeneration and lutein and zeaxanthin in the Carotenoids in Age-related Eye Disease Study (CAREDS): Ancillary study of the Women's Health Initiative. Arch. Ophthalmol 124: 1151-1162.

42. LaRowe TL, Mares JA, Snodderly DM, Klein ML, Wooten BR, et al (2008) Macular pigment density and age-related maculopathy in the Carotenoids in Age-Related Eye Disease Study. An ancillary study of the women's health initiative. Ophthalmology115(5): 876-883.

43. Korobelnik J, Rougier M, Delyfer M, Bron A, Merle B, et al. (2017) Effect of Dietary Supplementation with Lutein, Zeaxanthin, and omega-3 on Macular Pigment: A Randomized Clinical Trial. JAMA ophthalmology 135(11): 1259-1266.

44. Arslan S, Kadayifcilar S, Samur G (2019) The potential role of dietary antioxidant capacity in preventing age-related macular degeneration. J Am Coll Nutr 38(5): 424-432.

45. Rinninella E, Mele M, Merendino N, Cintoni M, Anselmi G, et al. (2018) The role of diet, micronutrients, and the gut microbiota in age-related macular degeneration: new perspectives from the Gut (-) Retina Axis. Nutrients 10(11): 1677.

46. Ma L, Dou H, Wu Y, Huang Y, Huang Y, et al. (2012) Lutein and zeaxanthin intake and the risk of age-related macular degeneration: A systematic review and meta-analysis. Br J Nutr 107(3): 350-359.

47. Boulton M, Docchio F, Dayhaw-Barker P, Ramponi R, Cubeddu R (1990) Age-related changes in the morphology, absorption and fluorescence of melanosomes and lipofuscin granules of the retinal pigment epithelium. Vision Res 30(9): 1291-1303.

48. Bernstein P, Khachik F, Carvalho L, Muir G, Zhao D, et al. (2001) Identification and quantitation of carotenoids and their metabolites in the tissues of the human eye. Exp Eye Res 72(3): 215-223.
49. Bhosale P, Serban B, Bernstein P (2009) Retinal carotenoids can attenuate formation of $\mathrm{A} 2 \mathrm{E}$ in the retinal pigment epithelium. Arch Biochem Biophys 483(2): 175-181.

50. Sparrow J, Nakanishi K, Parish C (2000) The lipofuscin fluorophore A2E mediates blue light-induced damage to retinal pigmented epithelial cells. Invest Ophthalmol Vis Sci 41(7): 1981-1989.

51. Winkler B, Boulton M, Gottsch J, Sternberg P (1999) Oxidative damage and age-related macular degeneration. Mol Vis 5: 32.

52. Conn P, Schalch W, Truscott T (1991) The singlet oxygen and carotenoid interaction. J Photochem Photobiol B 11(1): 41-47.

53. Khandhadia S, Cipriani V, Yates J, Lotery A (2012) Age-related macular degeneration and the complement system. Immunobiology 217(2): 127-146.

54. Jarrett S, Boulton M (2012) Consequences of oxidative stress in agerelated macular degeneration. Mol Aspects Med 33(4): 399-417.

55. Eye Disease Case-Control Study Group (1993) Antioxidant status and neovascular age-related macular degeneration. Arch Ophthalmol 111(1): 104-109.

56. Bone R, Landrum J, Mayne S, Gomez C, Tibor S, et al. (2001) Macular pigment in donor eyes with and without AMD: a case-control study. Invest Ophthalmol Vis Sci 42(1):235-240.

57. Fahey JW, Zhang Y, Talalay P (1997) Broccoli sprouts: An exceptionally rich source of inducers of enzymes that protect against chemical carcinogens. Proc Natl Acad Sci, USA 94(19): 10367-10372.

58. Gao X, Dinkova-Kostova AT, Talalay P (2001) Powerful and prolonged protection of human retinal pigment epithelial cells, keratinocytes, and mouse leukemia cells against oxidative damage: The indirect antioxidant effects of sulforaphane. Proc Natl Acad Sci USA 98(26): 15221-15226.

59. Gao X, Talalay P (2004) Induction of phase 2 genes by sulforaphane protects retinal pigment epithelial cells against photooxidative damage. Proc Natl Acad Sci, USA101(28): 10446-10451.

60. Hernández-Rabaza V, López-Pedrajas R, Almansa I (2019) Progesterone, lipoic acid, and sulforaphane as promising antioxidants for retinal diseases: a review. Antioxidants (Basel) 8(3): 53.

61. Li W, Kong AN (2009) Molecular mechanisms of Nrf2-mediated antioxidant response. Mol Carcinog 48(2):91-104.

62. Kang KW, Lee SJ, Kim SG (2005) Molecular mechanism of Nrf2 activation by oxidative stress. Antioxid Redox Signal 7(11-12): 16641673

63. Carlsen M, Halvorsen B, Holte K, Bøhn S, Dragland S, et al. (2010) The total antioxidant content of more than 3100 foods, beverages, spices, herbs and supplements used worldwide Nutr J 9:3.

64. Sarks S, Penfold P, Killingsworth M, van Driel D (1985) Patterns in macular degeneration. In: Ryan S, Dawson A, Little H, eds. Retinal Diseases. Orlando: Grune \& Stratton, pp. 87-93.

65. Penfold P, Killingsworth M, Sarks S (1986) Senile macular degeneration: the involvement of giant cells in atrophy of the retinal pigment epithelium. Investig Ophthalmol Vis Sci 27(3): 364-371.

66. Ambati J, Ambati BK, Yoo SH, Ianchulev S, Adamis AP (2003) Agerelated macular degeneration: etiology, pathogenesis and therapeutic strategies. Surv Ophthalmol 48(3): 257-293.

67. Crabb JW, Miyagi M, Gu X, Shadrach K, West KA, et al. (2002) Drusen proteome analysis: an approach to the etiology of age-related macular degeneration. Proc Natl Acad Sci USA 99(23): 14682-14687.

68. Anderson D, Mullins R, Hageman G, Johnson L (2002) A role for local inflammation in the formation of drusen in the aging eye. Am J Ophthalmol 134(3): 411-431. 
69. Hageman GS, Luthert PJ, Chong NHV, Johnson LV, Anderson DH, et al (2001) An integrated hypothesis that considers drusen as biomarkers of immune-mediated processes at the RPE-Bruch's membrane interface in aging and age-related macular degeneration. Prog Retin Eye Res 20(6): 705-732.

70. Penfold P, Madigan M, Gillies M, Provis J (2001) Immunological and aetiological aspects of macular degeneration. Prog Retin Eye Res 20(3): 385-414.

71. Mitta VP, Christen WG, Glynn RJ, Semba RD, Ridker PM, et al. (2013) $\mathrm{C}$-reactive protein and the incidence of macular degeneration: pooled analysis of 5 cohorts. JAMA Ophthalmol 131(4): 507-513.

72. Szeto Y, Kwok T, Benzie I (2004) Effects of long-term vegetarian diet on biomarkers of antioxidant status and cardiovascular disease risk. Nutr 20(10): 863-866.

73. Haghighatdoost F, Bellissimo N, deZepetnek J, Rouhani M (2017) Association of vegetarian diet with inflammatory biomarkers: a systematic review and meta-analysis of observational studies. Public Health Nutr 20(15): 2713-2721.

74. Shah B, Newman J, Woolf K, Ganguzza L, Guo Y, et al. (2018) Antiinflammatory effects of a vegan diet versus the American Heart Association-recommended diet in coronary artery disease trial. J Am Heart Assoc 7(23): e011367.

75. Sommerburgb O, Keunenc JEE, Birdd AC, van Kuijka FJGM (1998) Fruits and vegetables that are sources for lutein and zeaxanthin: the macular pigment in human eyes. Br J Ophthalmol 82(8): 907-910.

76. Perry A, Rasmussen H, Johnson E (2009) Xanthophyll (lutein, zeaxanthin) content in fruits, vegetables and corn and egg products. J Food Comp Anal 22(1): 9-15.

77. Evans J, Lawrenson J (2017) Antioxidant vitamin and mineral supplements for slowing the progression of age-related macular degeneration. Cochrane Database of Systematic Reviews 2017(7): CD000254.

78. Morazzoni P, Bombardelli E (1996) Vaccinium myrtillus. Fitoterapia (Milano) 67: 3-29.

79. Wang S, Feng R, Bowman L, Penhallegon R, Ding M, et al. (2005) Antioxidant activity in lingonberries (Vaccinium vitis-idaea L.) and its inhibitory effect on activator protein-1, nuclear factor-kappaB, and mitogen-activated protein kinases activation. J Agric Food Chem 53(8): 3156-3166.
80. Miyake S, Takahashi N, Sasaki M, Kobayashi S, Tsubota K, et al. (2012) Vision preservation during retinal inflammation by anthocyanin-rich bilberry extract: cellular and molecular mechanism. Lab Investig 92(1): 102-109.

81. Ogawa K, Kuse Y, Tsuruma K, Kobayashi S, Shimazawa M, et al. (2014) Protective effects of bilberry and lingonberry extracts against blue light-emitting diode light-induced retinal photoreceptor cell damage in vitro. BMC Complement Altern Med 14: 120.

82. Lawrenson J, Evans J, Group CEaV (2015) Omega 3 fatty acids for preventing or slowing the progression of age-related macular degeneration. Cochrane Database Syst Rev 2015(4): CD010015.

83. Rose S, Strombom A (2018) A comprehensive review of the prevention and treatment of heart disease with a plant-based diet. J Cardiol \& Cardiovas Ther 12(5): 555847.

84. Strombom A, Rose S (2017) The prevention and treatment of Type II Diabetes Mellitus with a plant-based diet. Endocrin Metab Int J 5(5): 00138.

85. Rose S, Strombom A (2020) Preventing stroke with a plant-based diet. Open Access J Neurol Neurosurg 14(2): 555882.

86. Rose S, Strombom A (2019) Osteoarthritis prevention and treatment with a plant-based diet. Ortho \& Rheum Open Access J 15(3): 555914.

87. Rose S, Strombom A (2018) A plant-based diet prevents and treats prostate cancer. Canc Therapy \& Oncol Int J 11(3): 555813.

88. Rose S, Strombom A (2019) Colorectal Cancer Prevention with a PlantBased Diet. Canc Therapy \& Oncol Int J 15(2): 555906.

89. Rose S, Strombom A (2019) Diverticular Disease risk reduced with a plant-based diet. Adv Res Gastroenterol Hepatol. 14(2): 555884.

90. Rose S, Strombom A (2020) Ulcerative Colitis - prevention and treatment with a plant-based diet. Adv Res Gastroentero Hepatol 15(2): 555908.

91. Rose S, Strombom A (2018) Crohn's disease prevention and treatment with a plant-based diet. Adv Res Gastroentero Hepatol 9(1).

92. Rose S, Strombom A (2020) Preventing thyroid diseases with a plantbased diet, while ensuring adequate iodine status. Glob J Oto 21(4): 556069 .

93. Rose S, Strombom A (2018) Rheumatoid Arthritis - Prevention and Treatment with a Plant-Based Diet. Orth \& Rheum Open Access J 13(1): 555852 .

Your next submission with Juniper Publishers
will reach you the below assets
- Quality Editorial service
- Swift Peer Review
- Reprints availability
- E-prints Service
- Manuscript Podcast for convenient understanding
- Global attainment for your research
- Manuscript accessibility in different formats
( Pdf, E-pub, Full Text, Audio)
- Unceasing customer service
Track the below URL for one-step submission
https://juniperpublishers.com/online-submission.php

